Article

\title{
Susceptibility of Blood Orange Cultivars to Chilling Injury Based on Antioxidant System, Physiological and Biochemical Responses at Different Storage Temperatures
}

\author{
Fariborz Habibi 1,2, Asghar Ramezanian 1, Fabián Guillén 2, Domingo Martínez-Romero 2, María \\ Serrano $^{3}$ and Daniel Valero ${ }^{2, *}$ \\ 1 Department of Horticultural Science, School of Agriculture, Shiraz University, Shiraz, Iran.; \\ fariborz_h659@yahoo.com (F.H.); ramezanian@shirazu.ac.ir (A.R.) \\ 2 Department of Food Technology, University Miguel Hernández. Ctra. Beniel km. 3.2, 03312, Orihuela, \\ Alicante, Spain; fabian.guillen@umh.es (F.G.); dmromero@umh.es (D.M.R.) \\ 3 Department of Applied Biology, University Miguel Hernández. Ctra. Beniel km. 3.2, 03312, Orihuela, \\ Alicante, Spain; m.serrano@umh.es (M.S.) \\ * Correspondence: daniel.valero@umh.es; Tel.: +34-96-674-9743 (D.V.)
}

Received: 9 September 2020; Accepted: date; Published: date

\begin{abstract}
Susceptibility of four blood orange cultivars ('Moro', 'Tarocco', 'Sanguinello' and 'Sanguine') to chilling injury (CI) was studied. Antioxidant enzymes, physiological and biochemical changes were measured monthly at 2 and $5{ }^{\circ} \mathrm{C}$ plus 2 days at $20^{\circ} \mathrm{C}$ for shelf life. At 2 ${ }^{\circ} \mathrm{C}$, CI symptoms were higher than at $5{ }^{\circ} \mathrm{C}$, and 'Moro' and 'Tarocco' had significantly higher $\mathrm{CI}$ than 'Sanguinello' and 'Sanguine'. 'Moro' and 'Tarocco' had the highest electrolyte leakage, malondialdehyde, $\mathrm{H}_{2} \mathrm{O}_{2}$ and polyphenol oxidase activity and lower phenylalanine ammonia-lyase compared with 'Sanguinello' and 'Sanguine'. The scanning electron microscopy micrographs revealed that 'Moro' and 'Taroco' showed severe fractures in the flavedo due to CI. 'Sanguinello' and 'Sanguine' were more tolerant to $\mathrm{CI}$ due to an increase of catalase, ascorbate peroxidase and superoxide dismutase, which could prevent the loss of membrane integrity and alleviate CI symptoms. The order of susceptibility of cultivars to CI was 'Moro'> 'Tarocco'> 'Sanguine'> 'Sanguinello'.
\end{abstract}

Keywords: antioxidant enzymes; hydrogen peroxide; phenylalanine ammonia-lyase; proline; scanning electron microscopy

\section{Introduction}

Blood oranges belong to sweet orange species (Citrus sinensis L. Osbeck) and are recognized among the oranges due to the presence of anthocyanins in the flesh and sometimes in the fruit peel [1]. 'Moro', 'Tarocco', 'Sanguinello' and 'Sanguine' are the most important commercial cultivars of blood oranges [2] and they arose from a spontaneous bud mutation [3]. Blood oranges have gained popularity among consumers due to their content on bioactive compounds such as anthocyanins, ascorbic acid, hydroxycinnamic acids, and flavonoids [4]. Distinct pomological characteristics of these cultivars are fruit size, rind thickness and anthocyanin pigmentation in the flesh and peel [5]. For example, 'Moro' is medium size and has sweet flavour with a deep red juice colour and bright red blush rind. 'Tarocco' is medium to large fruit size, with a low red juice colour, sweetness and juiciness, and has slightly blushed rind. 'Sanguinello' is smaller than the other fruits, less round but rather oval to egg-shaped, with few or no seeds, reddish compact peel and sweet and tender flesh. 'Sanguine' is a thin peel cultivar, having good juice colour and easy to peel. 
Chilling stress can induce oxidative damage in citrus fruit. Oxidative damage results in the generation of reactive oxygen species (ROS) and is thought to be a response of sensitive fruit to chilling temperatures that can affect cell membrane integrity [6]. In these conditions, enzymatic and non-enzymatic antioxidant systems can scavenge the ROS, whereas proline synthesis can maintain the cellular membrane integrity by osmoregulation and increase resistance of fruit to chilling temperature [7].

Blood oranges exhibit some responses at the cellular level after exposure to cold stress. The common responses include changes in cell structure, fatty acid saturation index, lipid peroxidation, electrolyte leakage (EL), proline content, hydrogen peroxide $\left(\mathrm{H}_{2} \mathrm{O}_{2}\right)$, malondialdehyde (MDA), activity of antioxidant enzymes and epidermis structure, among others. In addition, chilling stress can change the cellular metabolism and reduce cell energy status and leading to chilling injury (CI) symptoms such scalding, rind pitting and necrotic areas, watery breakdown, and browning [8-10].

Blood oranges are sensitive to cold stress and exhibit CI symptoms when stored at temperature lower than $5{ }^{\circ} \mathrm{C}$, depending on cultivars and storage temperatures [8]. However, storage of blood orange at cold temperatures is necessary for extending their postharvest life [1]. In recent years, some postharvest treatments such as $\gamma$-aminobutyric acid (GABA), methyl jasmonate (MeJA) and methyl salicylate (MeSA) have been applied for increasing chilling tolerance of blood oranges as well as controlling the peel physiological disorders [8]. Blood oranges have been stored up to 4 and 5 months at 8 and $3{ }^{\circ} \mathrm{C}$, respectively, although depending on cultivars [11]. To date, there is no scientific report on physiological and biochemical responses of blood orange cultivars to chilling stress during long-term storage. Physiological and biochemical studies may provide a very useful information about the involved mechanisms for chilling tolerance of blood orange cultivars in response to cold stress and how these responses are different among cultivars. Therefore, the objective of this study was to assess the susceptibility of blood orange cultivars, 'Moro', 'Tarocco', 'Sanguinello' and 'Sanguine' to $\mathrm{CI}$ when stored at 2 and $5{ }^{\circ} \mathrm{C}$ (chilling temperatures). In addition, the physiological and biochemical responses occurring during 6 months of storage and the role of antioxidant system on increasing CI tolerance will be evaluated.

\section{Materials and Methods}

\subsection{Plant material and storage conditions}

Blood oranges (Citrus sinensis L. Osbeck) cultivars, 'Moro', 'Tarocco', 'Sanguinello' and 'Sanguine' were harvested at mid-January 2018 from a commercial orchard at Dashtenaz company, Sari, Mazandaran, Iran (Latitude $36^{\circ} 33^{\prime} 47.95^{\prime \prime N}$, longitude $53^{\circ} 03^{\prime} 36.32^{\prime \prime E}$ ). In this area of Iran, the climate is subtropical and the 4 cultivars reach full maturity in January and were harvested at the same time and according to TSS/TA ratio of 7-8. Blood orange cultivars were immediately transported to the postharvest laboratory and selected based on uniformity of size and checked for no defects or rind injuries. Fruit were disinfected with $2 \% \mathrm{NaOCl}$ solution for 5 minutes, and then rinsed with distilled water. Fruit were divided into sets of three replicates and placed in polyethylene bags containing 16 holes and separately stored for up to 180 days at 2 or $5{ }^{\circ} \mathrm{C}$ and $90 \%$ relative humidity (RH). For each cultivar and temperature after $0,30,60,90,120,150$ and 180 days of cold storage, 5 fruits from each replicate were transferred 2 days at $20^{\circ} \mathrm{C}$ for the following analytical determinations in the flavedo tissue: Chilling injury (CI) index, electrolyte leakage (EL), MDA content, proline content, hydrogen peroxide $\left(\mathrm{H}_{2} \mathrm{O}_{2}\right)$ content, catalase (CAT), peroxidase (POD), ascorbate peroxidase (APX), superoxide dismutase (SOD), phenylalanine ammonia-lyase (PAL) and polyphenol oxidase (PPO) activities and total protein content. Scanning electron microscopy (SEM) micrographs of flavedo tissue were captured at the end storage. 


\subsection{CI index evaluation}

CI symptoms were determined by evaluation of rind pitting and necrotic areas of the cultivars during cold storage. Five fruit from the 3 replicates were visually evaluated on a four scale as 0 (no injury), 1 (slight injury), 2 (medium injury) and 3 (severe injury). CI index was measured using the following formula [12]:

$$
\mathrm{CI} \text { index }=\frac{\sum(\mathrm{CI} \text { level }) \times(\text { Number of fruit at } \mathrm{CI} \text { level })}{\text { Total number of fruit in the treatment }}
$$

\subsection{Peel thickness determination and electrolyte leakage (EL)}

Peel thickness was measured in recently harvested blood oranges (15 fruit) with a digital calliper, and results (mean $\pm \mathrm{SE}$ ) were expressed in $\mathrm{mm}$. For EL evaluation, ten discs of flavedo tissue were excised using a cork borer with a $0.5 \mathrm{~cm}$ diameter and rinsed twice with distilled water. The discs were inserted in $15 \mathrm{~mL}$-falcon tube containing $10 \mathrm{~mL}$ of $0.3 \mathrm{~mol} \mathrm{~L}^{-1}$ mannitol solution and shaken at room temperature for $3 \mathrm{~h}$. First conductivity (EC1) was measured after $3 \mathrm{~h}$ of shaking, and second (EC2) after boiling in water at $100{ }^{\circ} \mathrm{C}$ for $5 \mathrm{~min}$ and cooling down at room temperature, using a conductivity-meter (AZ-86505, Taiwan). The percentage of electrolyte leakage was calculated using the following formula [7]:

$$
\mathrm{EL}(\%)=\frac{\mathrm{ECl}}{\mathrm{EC} 2} \times 100
$$

\subsection{MDA content}

To evaluate the MDA content, $0.1 \mathrm{~g}$ of flavedo tissue were homogenized in $2 \mathrm{~mL}$ of $1 \%$ trichloroacetic acid (TCA) and centrifuged at 10,000 $\times g$ for $10 \mathrm{~min}$. Supernatant $(250 \mu \mathrm{L})$ was mixed with $1 \mathrm{~mL}$ of $20 \%$ TCA containing $0.5 \%$ thiobarbituric acid (TBA) and the mix was held in hot water at $90{ }^{\circ} \mathrm{C}$ for $30 \mathrm{~min}$, then immediately cooled in ice bath and centrifuged. Absorbance was read at 532, 600 and $450 \mathrm{~nm}$ by microplate reader spectrophotometer (Epoch Biotech, USA) and MDA was

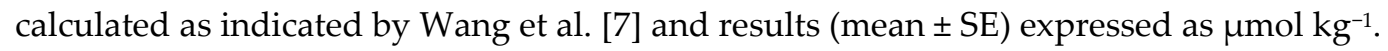

\subsection{Hydrogen peroxide $\left(\mathrm{H}_{2} \mathrm{O}_{2}\right)$ content}

Flavedo $(0.2 \mathrm{~g})$ were homogenized in $2 \mathrm{~mL}$ of $1 \%(\mathrm{w} / \mathrm{v})$ trichloroacetic acid (TCA) and centrifuged at $4{ }^{\circ} \mathrm{C}$ for $10 \mathrm{~min}$ at $10,000 \times g$. The supernatant $(250 \mu \mathrm{L})$ was then mixed with $250 \mu \mathrm{L}$ of $100 \mathrm{mmol} \mathrm{L}^{-1}$ phosphate buffer $(\mathrm{pH}=7)$ and $500 \mu \mathrm{L}$ of $1 \mathrm{~mol} \mathrm{~L}^{-1}$ of potassium iodide (KI) in a $2 \mathrm{~mL}$ Eppendorf tube. Then, the mixture solution was vortexed and its absorbance was read at $390 \mathrm{~nm}$ using a microplate reader spectrophotometer (Epoch Biotech, USA). The content of $\mathrm{H}_{2} \mathrm{O}_{2}$ was determined with a standard curve of $\mathrm{H}_{2} \mathrm{O}_{2}$ and results (mean $\pm \mathrm{SE}$ ) were expressed as mmol kg-1 fresh weight [13].

\subsection{Proline content}

To evaluate the proline content, $0.5 \mathrm{~g}$ of flavedo were homogenized in $10 \mathrm{~mL}$ of $3 \%(\mathrm{v} / \mathrm{v})$ sulfosalicylic acid and then centrifuged at $12,000 \times g$ for $10 \mathrm{~min}$. Two $\mathrm{mL}$ of the supernatant were mixed with $2 \mathrm{~mL}$ of glacial acetic acid and $2 \mathrm{~mL}$ of ninhydrin reagent in the test tube and held in hot water at $100{ }^{\circ} \mathrm{C}$ for $1 \mathrm{~h}$. Solution was cooled immediately in an ice bath and $4 \mathrm{~mL}$ of toluene were added to the reaction mixture, which was vortexed for $20 \mathrm{~s}$. The absorbance was measured at $520 \mathrm{~nm}$ by spectrophotometer (Dynamica, UK). The proline content was determined with a standard curve of proline and results (mean $\pm \mathrm{SE}$ ) expressed as $\mathrm{g} \mathrm{kg}^{-1}$ fresh weight [14]. 


\subsection{Enzyme activities determination}

For the enzyme extraction (CAT, APX, SOD and POD activities), $0.5 \mathrm{~g}$ of flavedo tissue were excised and ground in liquid nitrogen with a mortar and pestle, then homogenized with $2 \mathrm{~mL}$ of extraction buffer $\left(50 \mathrm{mmol} \mathrm{L}{ }^{-1}\right.$ potassium phosphate buffer, $\mathrm{pH}=7$, containing $2 \mathrm{mmol} \mathrm{L}^{-1}$ ethylene diamine tetraacetic acid and $1 \%$ polyvinylpyrrolidone) in a $2 \mathrm{~mL}$ Eppendorf tube and centrifuged at $13,000 \times g$ for $10 \mathrm{~min}$ at $4^{\circ} \mathrm{C}$. The supernatant was taken for measurement of all enzyme activities and total protein content [15]. All enzyme activities were measured by spectrophotometry (Dynamica, $\mathrm{UK}$ ) and the specific activity was expressed as $\mathrm{U} \mathrm{mg}^{-1}$ protein. CAT activity was measured by the $\mathrm{H}_{2} \mathrm{O}_{2}$ decomposition after $1 \mathrm{~min}$ of reaction at $240 \mathrm{~nm}$ [16]. APX activity was measured according to Nakano and Asada [17] by measuring the absorbance at $290 \mathrm{~nm}$. SOD activity was measured according to Beauchamp and Fridovich [18] method by measuring the absorbance at $560 \mathrm{~nm}$. POD activity was measured using guaiacol as substrate and after 2 min of reaction the absorbance was measured at $470 \mathrm{~nm}$ [16].

The PAL activity was determined by measuring the absorbance of trans-cinnamic acid at 290 $\mathrm{nm}$ [19]. For enzyme extraction, $0.5 \mathrm{~g}$ of fruit peel were excised and ground in liquid nitrogen with a mortar and pestle and then added $2 \mathrm{~mL}$ of extraction buffer (containing $100 \mathrm{mmol} \mathrm{L}^{-1}$ of sodium borate buffer ( $\mathrm{pH}=7), 5 \mathrm{mmol} \mathrm{L}-1 \quad \beta$-mercaptoethanol, and $1 \% \mathrm{PVP}$ ) and centrifuged at 13,000 $\times g$ during $20 \mathrm{~min}$ at $4{ }^{\circ} \mathrm{C}$. The activity of PPO was determined by method of Silva and Koblitz [20]. (2010) at $425 \mathrm{~nm}$. For enzyme extraction, $0.2 \mathrm{~g}$ of fruit peel excised and ground in liquid nitrogen with a mortar and pestle, then mixed with $2 \mathrm{~mL}$ of extraction buffer (containing $100 \mathrm{mmol} \mathrm{L}^{-1}$ of potassium phosphate buffer ( $\mathrm{pH}=7.8$ ) and $1 \% \mathrm{PVP})$, centrifuged at $13,000 \times \mathrm{g}$ for $15 \mathrm{~min}$ at $4{ }^{\circ} \mathrm{C}$. Results for all enzymes were expressed in $\mathrm{U} \mathrm{mg}^{-1}$ protein.

\subsection{Scanning electron microscopy (SEM) micrograph}

For preparing SEM images, flavedo tissue $(1 \times 1 \mathrm{~cm})$ from each cultivar were excised with a scalpel blade from the fruit equatorial area. Samples were lyophilized by freeze dryer (FD-5003-BT, Iran), and attached on a stub and the peel surface coated with a thin layer of gold (Desk Sputter Coater Dsr1 Nanostructural Coating). Digital SEM images were taken using a scanning electron microscope (Scanning Electron Microscope, TESCAN vega3, Czech) at 500× magnification [21].

\subsection{Statistical analyses}

The experiment was conducted according to a completely randomized design (CRD) with three replicates. Data were analysed using three-factors (cultivars, temperatures and storage times) analysis of variance (ANOVA). Mean comparisons were done by least significant difference (LSD) test $(\mathrm{P}<0.05)$ with standard errors of means. Data analyses were performed with SAS software package v. 9.4 for Windows. Hierarchical cluster analysis (HCA) was conducted using a Ward linkage method with Euclidean distance, and the data was depicted in a dendrogram plot by Minitab version 16 software. Correlation between peel thickness and CI at both temperatures were performed with SigmaPlot software.

\section{Results}

\subsection{CI index, peel thickness, EL and SEM micrograph}

CI index increased during storage for all cultivars and for both temperatures (Figure 1). CI symptoms appeared after 30 days of cold storage at both temperatures although, as expected, CI was significantly higher ( $42 \%$ more, on average) at 2 than at $5^{\circ} \mathrm{C}$ for all blood oranges along the 180 days of storage. Among cultivars, 'Moro' and 'Tarocco' showed significantly higher CI symptoms than 'Sanguine' and 'Sanguinello', the latter having the lowest CI. 


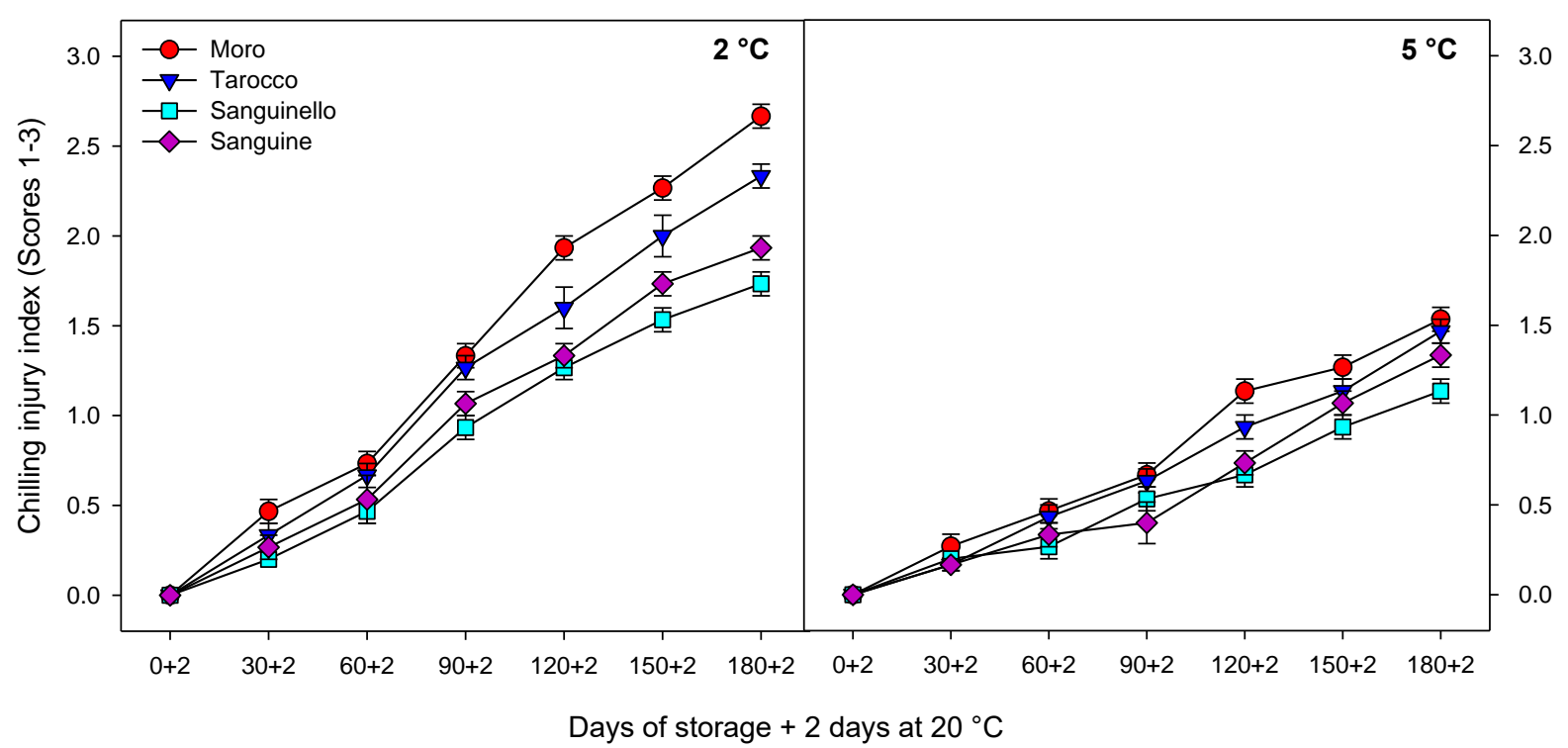

Figure 1. Chilling injury index of blood orange cultivars ('Moro', 'Tarocco', 'Sanguinello' and 'Sanguine') during 180 days of cold storage at 2 and $5{ }^{\circ} \mathrm{C}$ and $90 \% \mathrm{RH}$, and 2 days at $20^{\circ} \mathrm{C}$. Vertical bars represent \pm standard error (SE) of means and LSD $(p<0.05)$ value is 0.18 .

The cultivars differed in peel thickness, with 'Tarocco' being the thickest $(5.01 \pm 0.34 \mathrm{~mm})$, followed by 'Moro' $(4.52 \pm 0.11 \mathrm{~mm})$, 'Sanguinello' $(3.42 \pm 0.09 \mathrm{~mm})$ and 'Sanguine' $(2.93 \pm 0.08 \mathrm{~mm})$. Membrane permeability of blood orange cultivars was evaluated by measuring peel EL. As shown in Figure 2, EL significantly increased for all cultivars with a similar trend during 180 days of storage at both temperatures, although EL at $2{ }^{\circ} \mathrm{C}$ was greater than $5{ }^{\circ} \mathrm{C}$. 'Moro' had higher EL $(66.71 \pm 1.02 \%)$ than 'Tarocco', 'Sanguinello' and 'Sanguine'. Thus, at the end of storage, the lowest EL was observed in 'Sanguinello' cultivar at both temperatures, $52.07 \pm 3.46$ and $51.20 \pm 0.32 \%$, respectively. EL in 'Moro' was 3.5, 21.93, and $10.92 \%$ higher than 'Tarocco', 'Sanguinello' and 'Sanguine' cultivars, respectively at the last sampling date at $2{ }^{\circ} \mathrm{C}$.

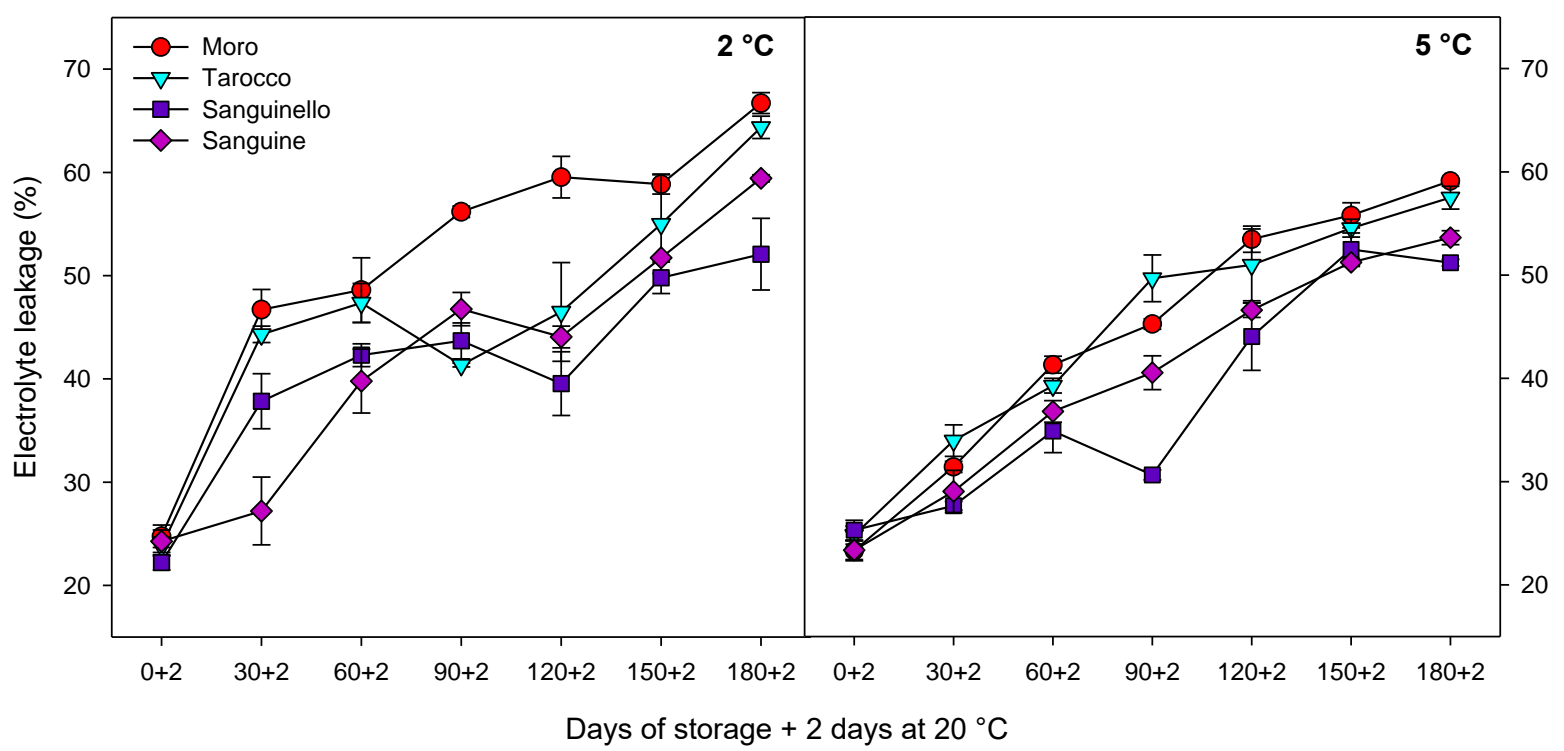

Figure 2. Electrolyte leakage (EL) of blood orange cultivars ('Moro', 'Tarocco', 'Sanguinello' and 'Sanguine') during 180 days of cold storage at 2 and $5{ }^{\circ} \mathrm{C}$ and $90 \% \mathrm{RH}$, and 2 days at $20^{\circ} \mathrm{C}$. Vertical bars represent \pm standard error (SE) of means and LSD $(p<0.05)$ value is 5.17 .

SEM micrographs were captured to study the epidermis structure of the peel at the 2 storage temperatures (Figure 3A-H), in which fractures and cuticular ridges at $2{ }^{\circ} \mathrm{C}$ were greater than $5{ }^{\circ} \mathrm{C}$ 
for all cultivars. 'Moro' and 'Tarocco' showed a rough structure with severe fractures and cuticular ridges of the peel in comparison with 'Sanguinello' and 'Sanguine' at $2{ }^{\circ} \mathrm{C}$ (Figure 3A-D). Moreover, visible fractures in 'Sanguinello' were less pronounced than 'Sanguine' (Figure 3C-D).

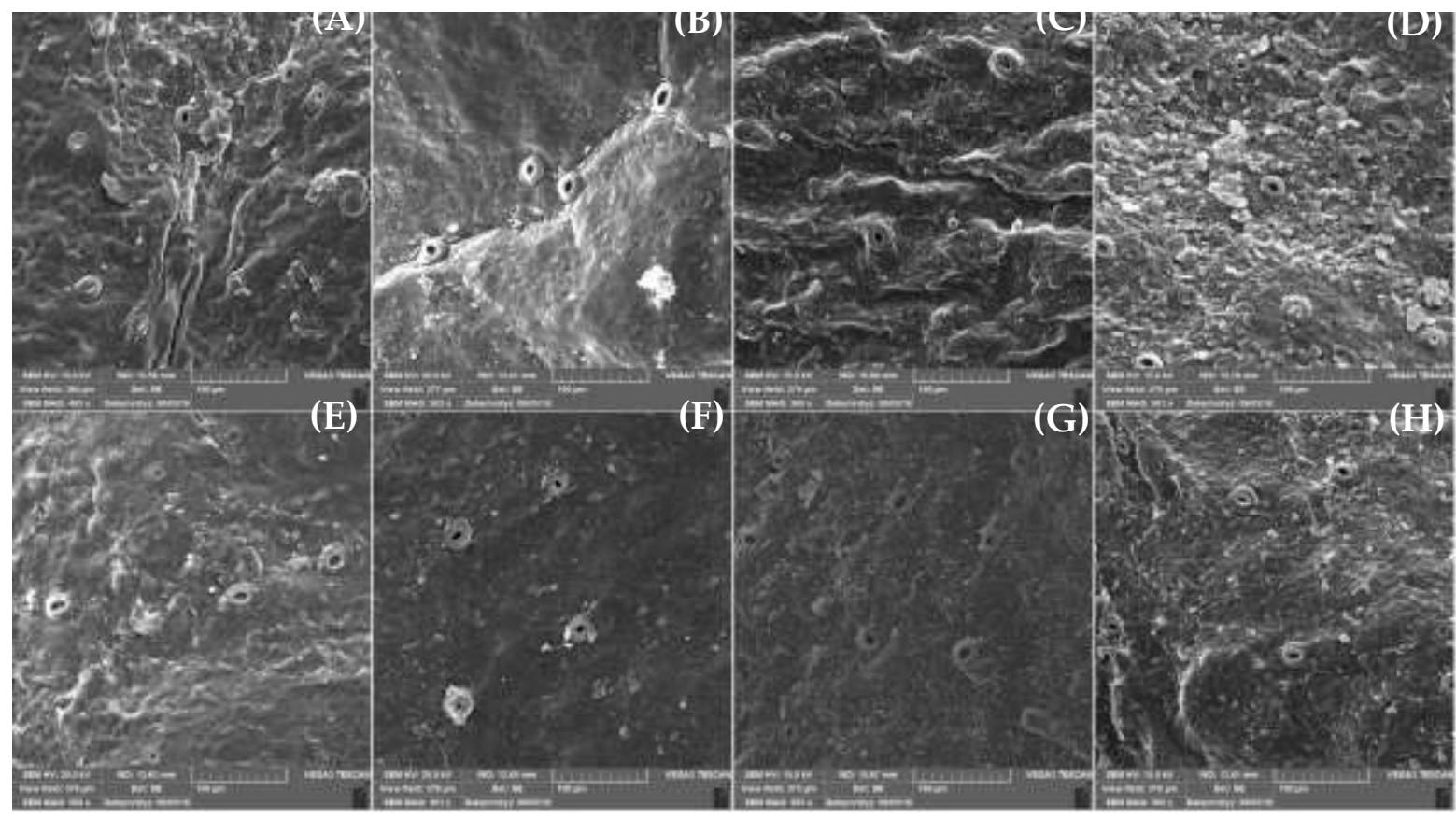

Figure 3. Scanning electron micrographs (500× magnification) of the flavedo of blood orange cultivars after 180 days of cold storage plus 2 days at $20^{\circ} \mathrm{C}$; (A) 'Moro' at $2{ }^{\circ} \mathrm{C}$; (B) 'Tarocco' at $2{ }^{\circ} \mathrm{C}$; (C) 'Sanguinello' at $2{ }^{\circ} \mathrm{C}$; (D) 'Sanguine' at $2{ }^{\circ} \mathrm{C}$; (E) 'Moro' at $5{ }^{\circ} \mathrm{C}$; (F) 'Tarocco' at $5{ }^{\circ} \mathrm{C}$; (G) 'Sanguinello' at $5{ }^{\circ} \mathrm{C} ;(\mathrm{H})$ 'Sanguine' at $5{ }^{\circ} \mathrm{C}$.

The micrographs also showed that epicuticular wax crystals were lost and the remaining wax layer acquired an irregular morphology due to $\mathrm{CI}$ at $2{ }^{\circ} \mathrm{C}$. Cultivars stored at $5{ }^{\circ} \mathrm{C}$ had an intact peel surface, without the appearance of severe fractures, but epicuticular wax was also lost for all blood oranges (Figure 3E-H). Among cultivars, 'Moro' and 'Tarocco' had lower epicuticular wax and more granular surface in comparison with 'Sanguinello' and 'Sanguine' cultivars (Figure 3E-F). Interestingly, 'Sanguinello' had a fine structure of epicuticular wax, with no wrinkling signs and lower granule surface in comparison with 'Sanguine' (Figure 3G-H).

\section{2. $\mathrm{H}_{2} \mathrm{O}_{2}, \mathrm{MDA}$ and proline content}

The $\mathrm{H}_{2} \mathrm{O}_{2}$ accumulation was affected by cultivars, storage times and temperatures (Figure 4). The $\mathrm{H}_{2} \mathrm{O}_{2}$ content increased sharply in blood orange cultivars up to 120 days of cold storage. However, $\mathrm{H}_{2} \mathrm{O}_{2}$ content at $2{ }^{\circ} \mathrm{C}$ was a $16 \%$ higher (on average) than at $5{ }^{\circ} \mathrm{C}$. 'Tarocco' and 'Moro' had the highest $\mathrm{H}_{2} \mathrm{O}_{2}$ content at $2{ }^{\circ} \mathrm{C}\left(1.61 \pm 0.01\right.$ and $1.51 \pm 0.01 \mathrm{nmol} \mathrm{kg}{ }^{-1}$, at 90 and 120 days, respectively) without significant differences between them. Contrarily, the lowest $\mathrm{H}_{2} \mathrm{O}_{2}$ content was measured in 'Sanguinello' and 'Sanguine'. 


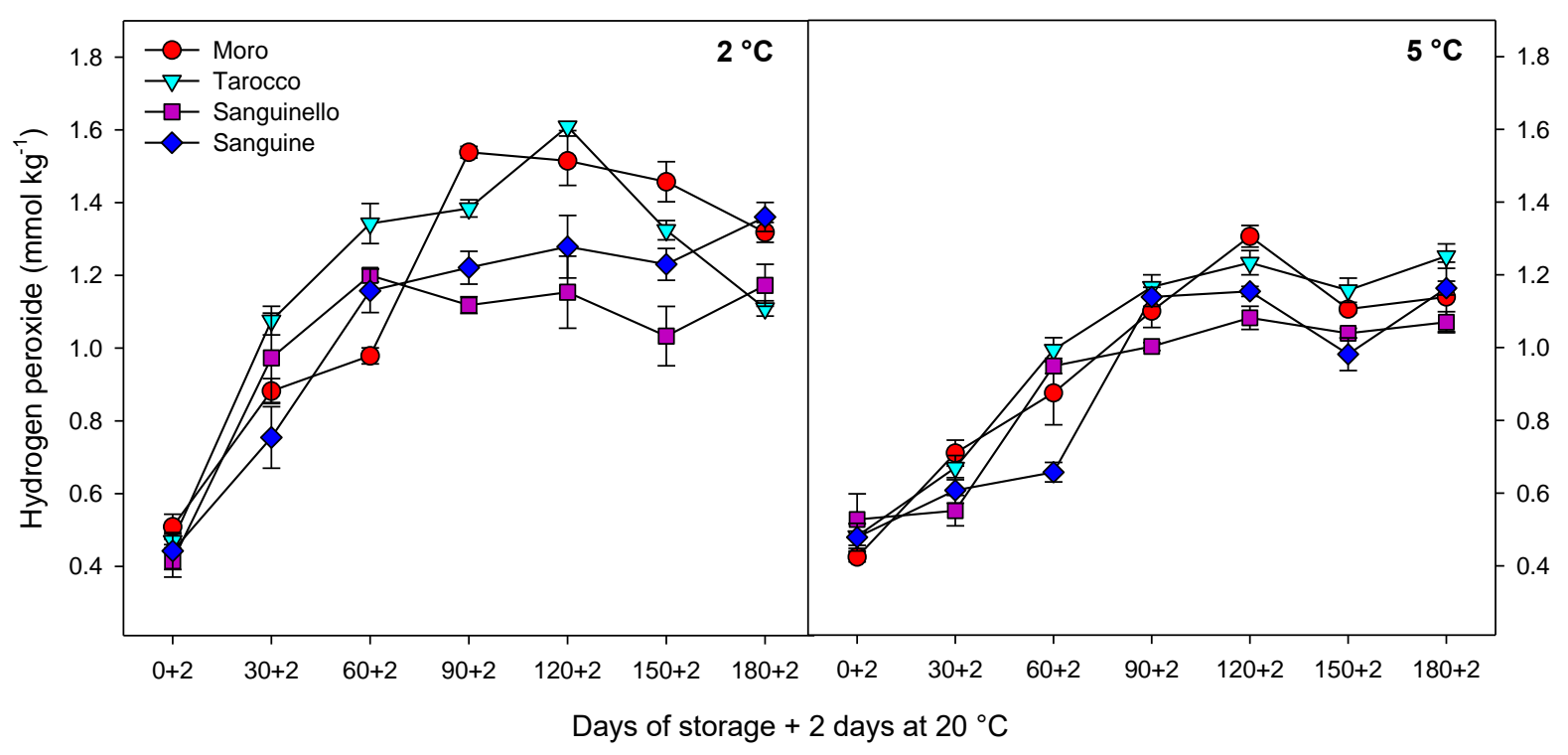

Figure 4. Changes in hydrogen peroxide $\left(\mathrm{H}_{2} \mathrm{O}_{2}\right)$ content in the flavedo of blood orange cultivars ('Moro', 'Tarocco', 'Sanguinello' and 'Sanguine') during cold storage at 2 and $5{ }^{\circ} \mathrm{C}$ and $90 \% \mathrm{RH}$ plus 2 days at $20^{\circ} \mathrm{C}$. Vertical bars represent \pm standard error (SE) of means. LSD $(p<0.05)$ value is 0.19 .

There was a significant difference on MDA among cultivars at different storage times and temperatures. MDA content increased up to 150 and 120 days at 2 and $5{ }^{\circ} \mathrm{C}$, respectively on all cultivars, although levels were reduced in 'Sanguine' and 'Sanguinello' (Figure 5). Similarly to $\mathrm{H}_{2} \mathrm{O}_{2}$, the highest MDA content was measured in 'Tarocco' after 120 days storage at $2{ }^{\circ} \mathrm{C}$ and also MDA content at $2{ }^{\circ} \mathrm{C}$ was $20.47 \%$ higher than at $5{ }^{\circ} \mathrm{C}$.

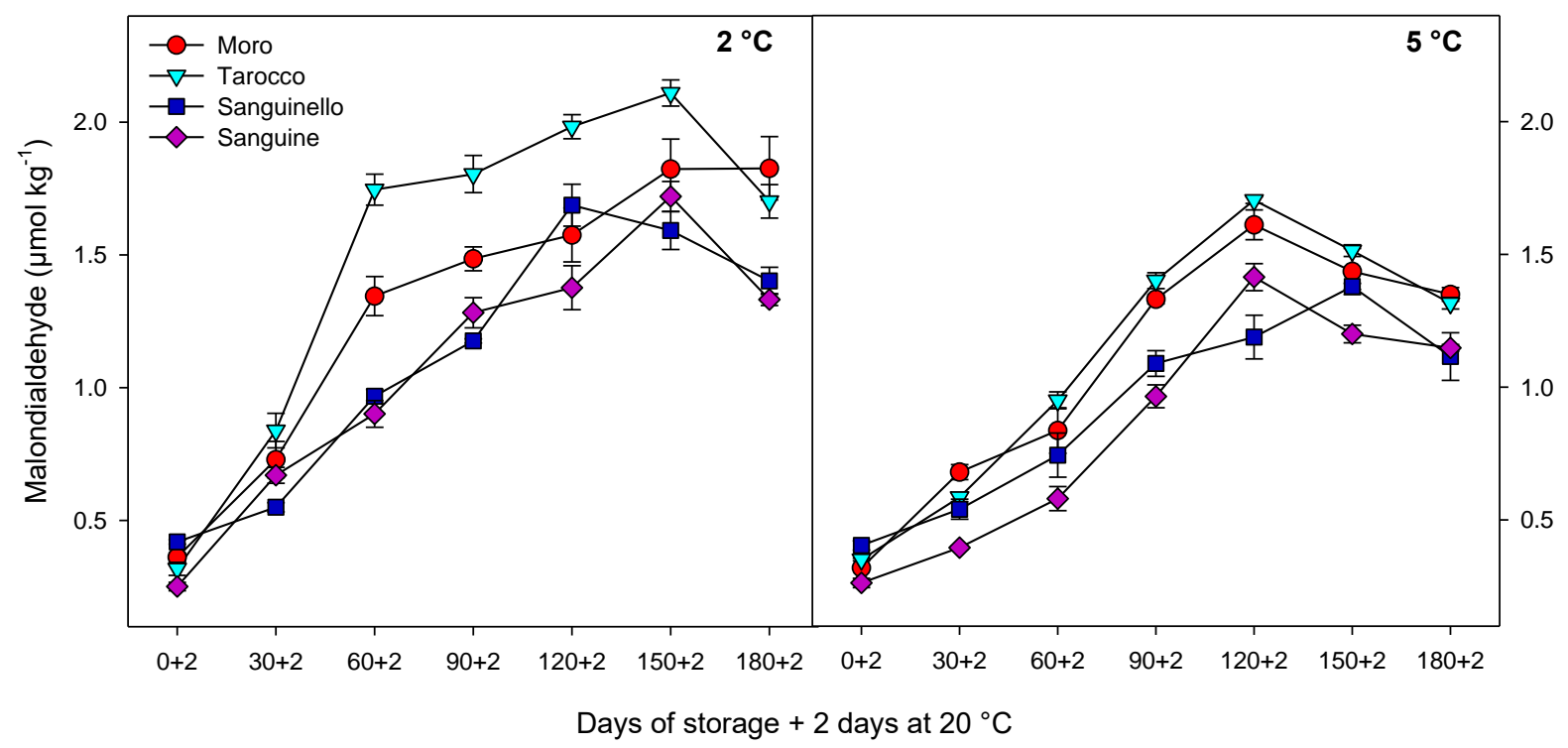

Figure 5. Changes in malondialdeyde (MDA) content in the flavedo of blood orange cultivars ('Moro', 'Tarocco', 'Sanguinello' and 'Sanguine') during cold storage at 2 and $5{ }^{\circ} \mathrm{C}$ and $90 \% \mathrm{RH}$ plus 2 days at $20^{\circ} \mathrm{C}$. Vertical bars represent \pm standard error (SE) of means. LSD $(p<0.05)$ value is 0.22 .

As shown in Figure 6, proline content gradually increased during cold storage and then decreased. On average, proline content at $5{ }^{\circ} \mathrm{C}$ was $6.61 \%$ higher than $2{ }^{\circ} \mathrm{C}$. 'Sanguinello' had higher proline content than 'Moro', 'Tarocco', and 'Sanguine' cultivars. After 120 days of storage, the highest proline content was measured in 'Sanguinello' at both temperatures. 


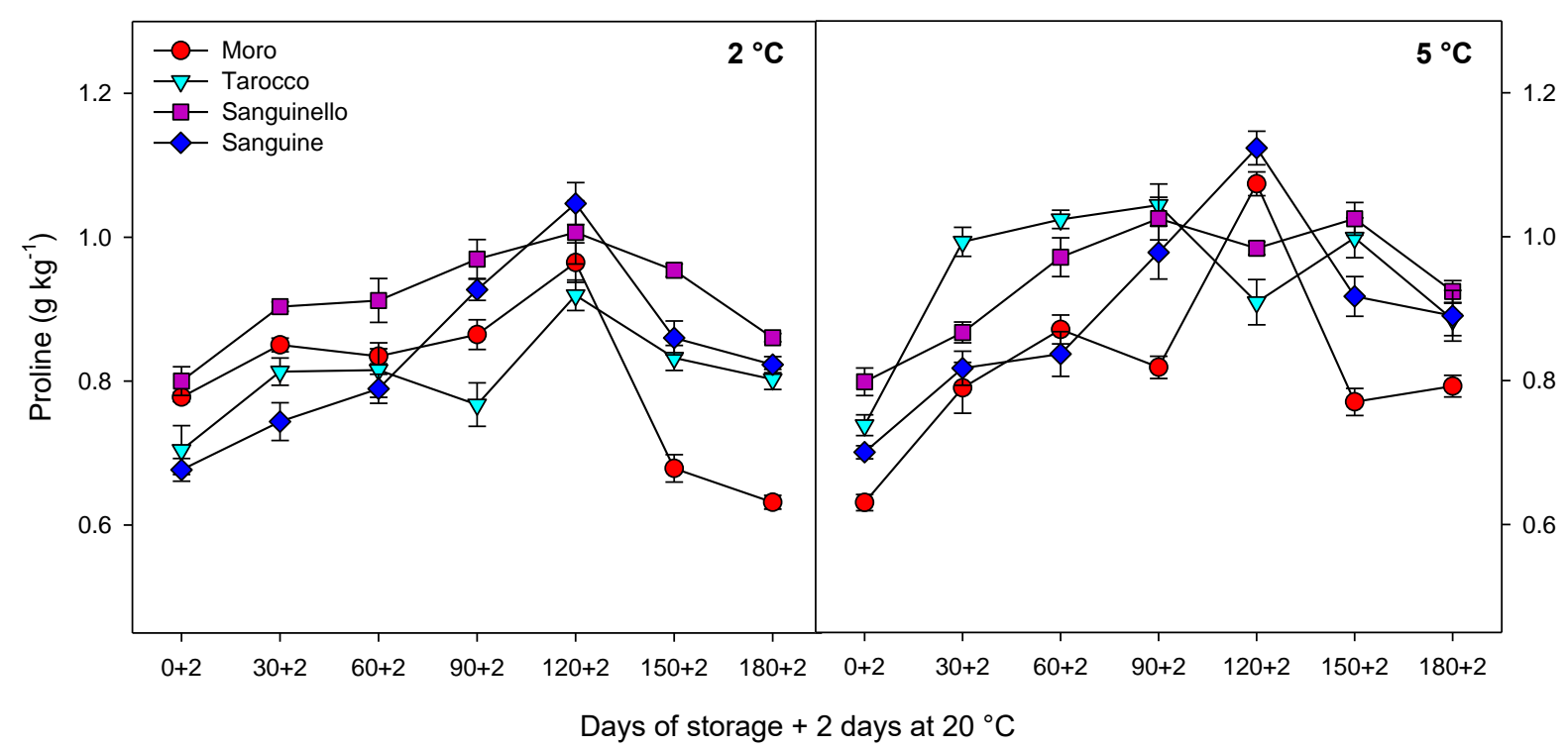

Figure 6. Changes in proline content in the flavedo of blood orange cultivars ('Moro', 'Tarocco', 'Sanguinello' and 'Sanguine') during cold storage at 2 and $5{ }^{\circ} \mathrm{C}$ and $90 \% \mathrm{RH}$ plus 2 days at $20{ }^{\circ} \mathrm{C}$. Vertical bars represent \pm standard error (SE) of means. LSD $(p<0.05)$ value is 0.13 .

\subsection{Antioxidant enzyme activities}

Antioxidant enzymes (CAT, APX, SOD and POD) activities in the flavedo tissue were affected by cultivars, storage times and temperatures (Figures 7-10). CAT activity was significantly higher at 5 than $2{ }^{\circ} \mathrm{C}$ for all blood oranges cultivars (Figure 7). CAT activity increased up to 60 or 90 days for all cultivars at both temperatures. Among cultivars, 'Moro' and 'Tarocco' had the lowest level of CAT activity at both temperatures, while 'Sanguinello' and 'Sanguine' showed higher CAT activity than 'Moro' and 'Tarocco'. However, there was no significant difference between 'Sanguinello' and 'Sanguine' for CAT activity. The highest CAT activity was measured in 'Sanguinello' after 60 days at $2{ }^{\circ} \mathrm{C}$ and after 90 days of storage at $5{ }^{\circ} \mathrm{C}$ (Figure 7).

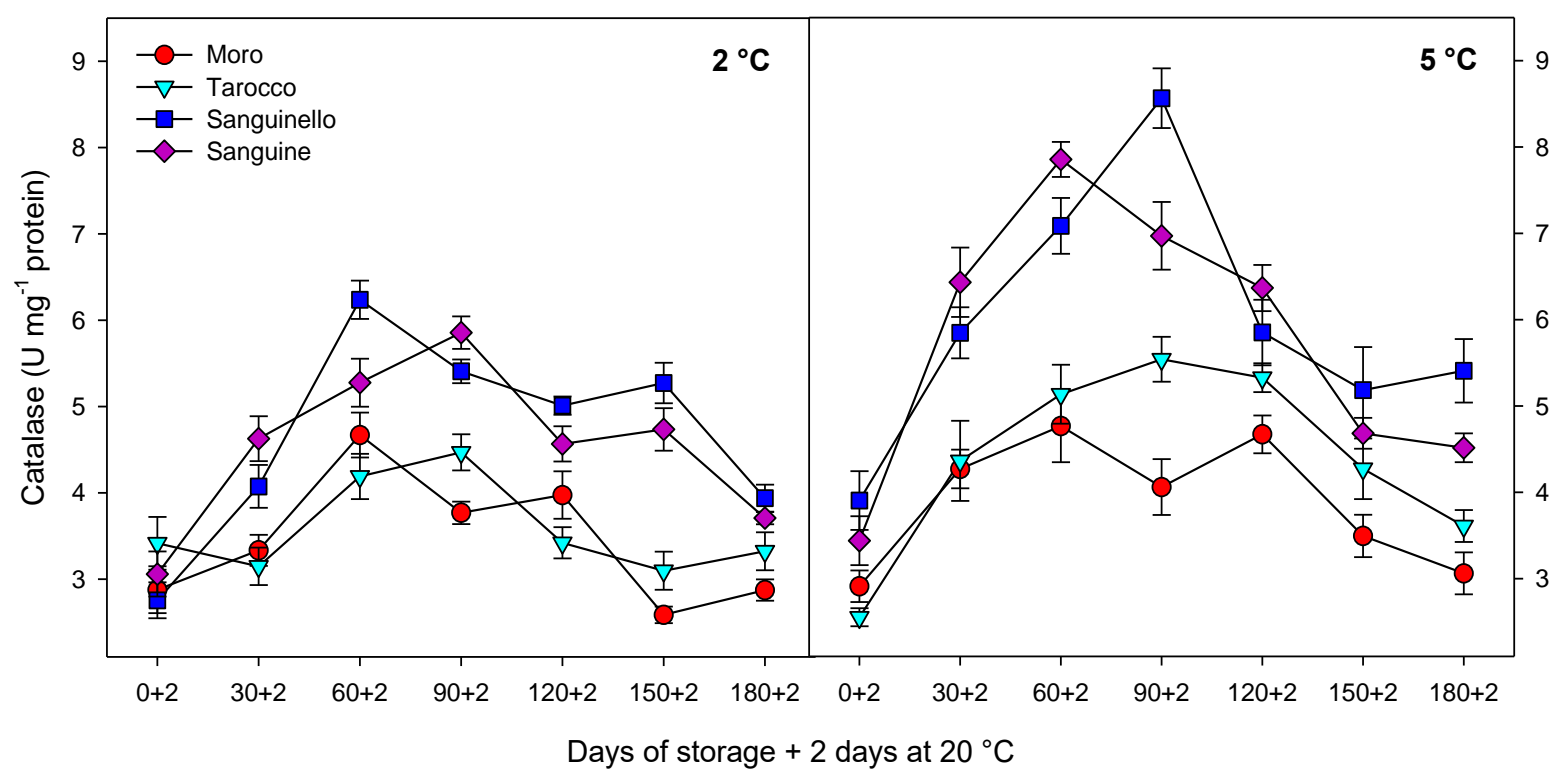

Figure 7. Changes in catalase (CAT) enzyme activity in the flavedo of blood orange cultivars ('Moro', 'Tarocco', 'Sanguinello' and 'Sanguine') during cold storage at 2 and $5{ }^{\circ} \mathrm{C}$ and $90 \% \mathrm{RH}$ plus 2 days at $20^{\circ} \mathrm{C}$. Vertical bars represent \pm standard error (SE) of means. LSD $(p<0.05)$ value is 1.10 . 
APX activity had a significant difference among the cultivars. At both temperatures, 'Moro' and 'Sanguinello' had the lowest and the highest APX activity, respectively (Figure 8). However, on average, APX activity at $5{ }^{\circ} \mathrm{C}$ was $23 \%$ greater than at $2{ }^{\circ} \mathrm{C}$. APX activity increased for all cultivars at days 60-90 and then decreased along the storage at both temperatures. The highest APX activity was measured in 'Sanguinello' after 90 days at $2{ }^{\circ} \mathrm{C}$.

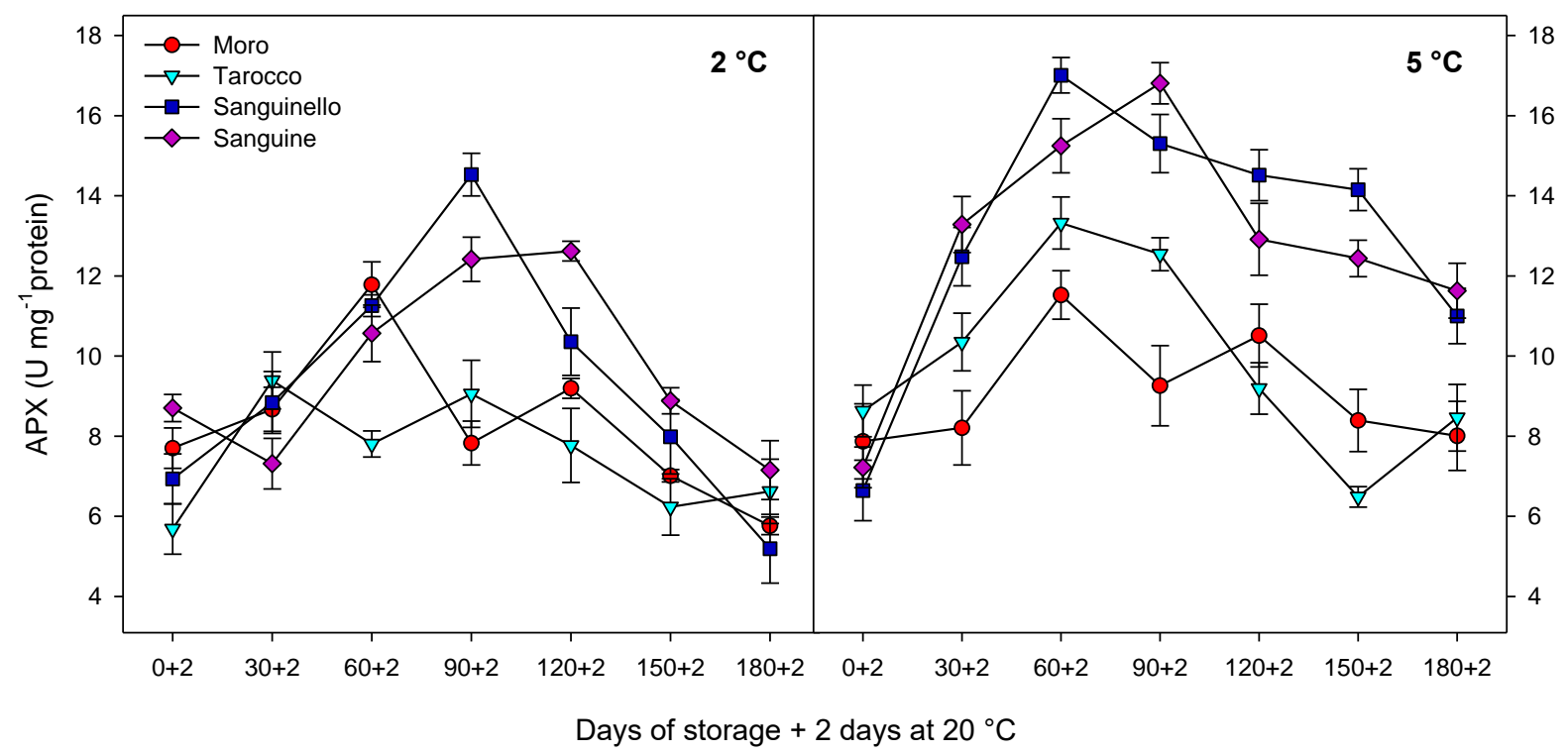

Figure 8. Changes in ascorbate peroxidase (APX) enzyme activity in the flavedo of blood orange cultivars ('Moro', 'Tarocco', 'Sanguinello' and 'Sanguine') during cold storage at 2 and $5{ }^{\circ} \mathrm{C}$ and $90 \%$ $\mathrm{RH}$ plus 2 days at $20^{\circ} \mathrm{C}$. Vertical bars represent \pm standard error (SE) of means. $\operatorname{LSD}(p<0.05)$ value is $2.31,0.61$.

SOD activity of cultivars was affected at both temperatures during storage (Figure 9). 'Moro' and 'Tarocco' had the lowest SOD activity at $5^{\circ} \mathrm{C}$. However, the highest SOD activity was found in 'Sanguinello' and 'Sanguine' without significant differences. As shown in Figure 9, SOD activity sharply increased for all cultivars up to 60 days storage at $5{ }^{\circ} \mathrm{C}$ and then decreased to the end of storage. This trend was similar at $2{ }^{\circ} \mathrm{C}$, however, SOD activity slightly increased in 'Tarocco' and 'Sanguinello' at the end of storage. 


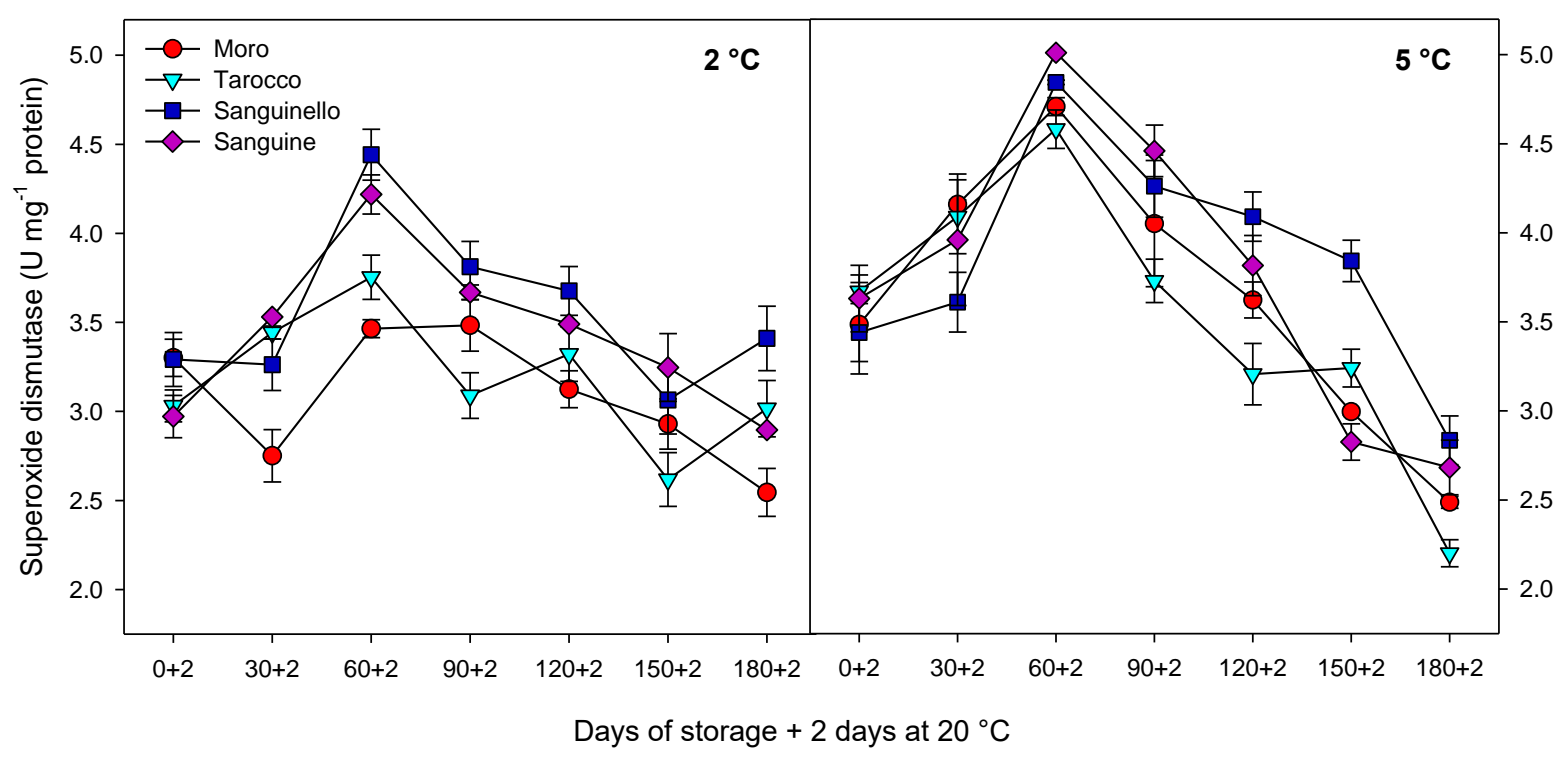

Figure 9. Changes in superoxide dismutase (SOD) enzyme activity in the flavedo of blood orange cultivars ('Moro', 'Tarocco', 'Sanguinello' and 'Sanguine') during cold storage at 2 and $5{ }^{\circ} \mathrm{C}$ and $90 \%$ RH plus 2 days at $20^{\circ} \mathrm{C}$. Vertical bars represent \pm standard error (SE) of means. LSD $(p<0.05)$ value is 0.61 .

POD activity was significantly different among cultivars at both temperatures (Figure 10). POD activity at $5{ }^{\circ} \mathrm{C}$ was $20.1 \%$ higher than at $2{ }^{\circ} \mathrm{C}$. 'Tarocco' had the lowest POD activity at $2{ }^{\circ} \mathrm{C}$ while the highest POD activity was found in 'Sanguinello' after 60 days at $5{ }^{\circ} \mathrm{C}$. However, there was no significant difference 'Moro' and 'Sanguine' for POD activity at both temperatures.

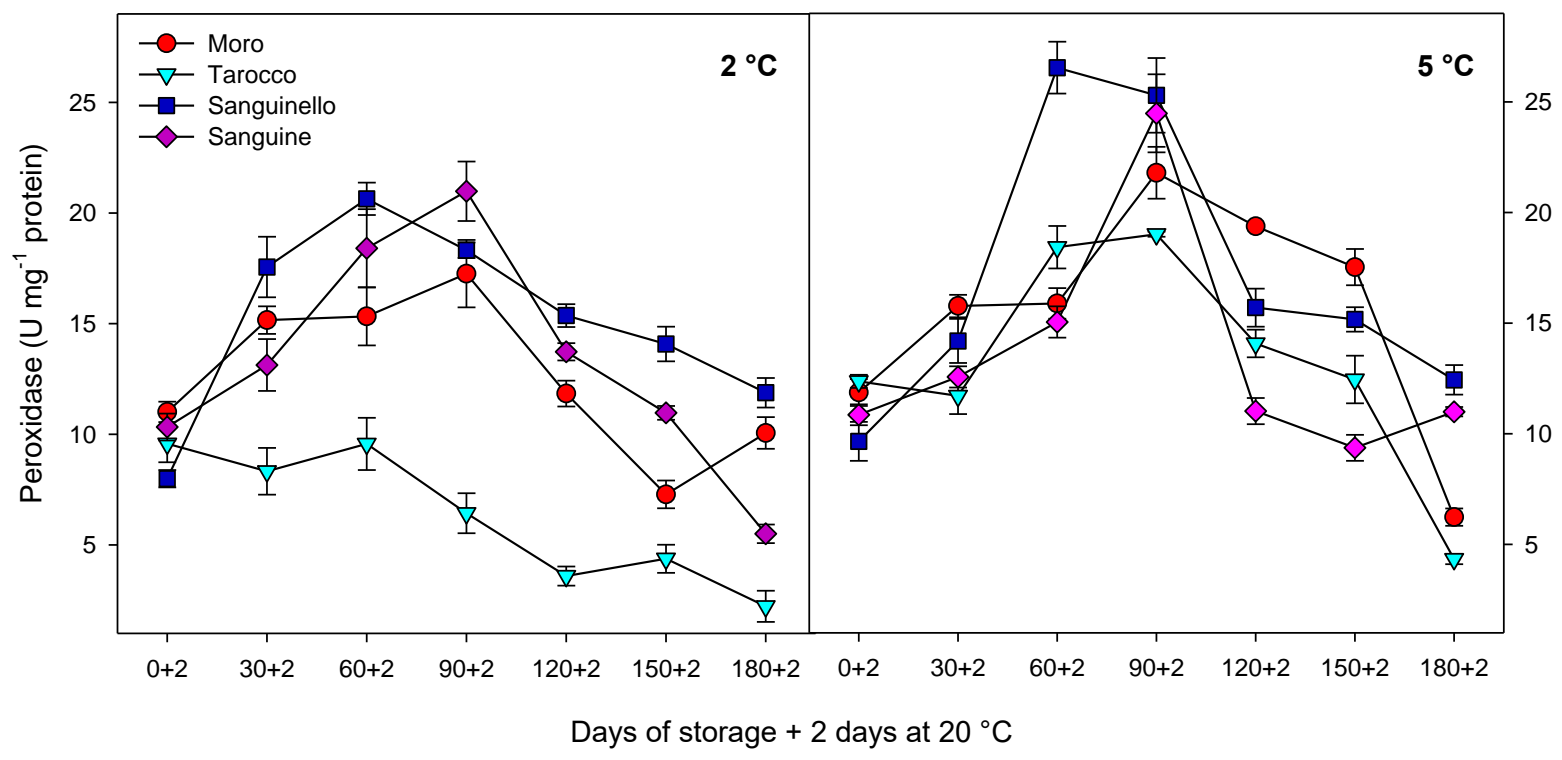

Figure 10. Changes in peroxidase (POD) enzyme activity in the flavedo of blood orange cultivars ('Moro', 'Tarocco', 'Sanguinello' and 'Sanguine') during cold storage at 2 and $5{ }^{\circ} \mathrm{C}$ and $90 \% \mathrm{RH}$ plus 2 days at $20^{\circ} \mathrm{C}$. Vertical bars represent \pm standard error (SE) of means. LSD $(p<0.05)$ value is 3.12 .

\subsection{PAL and PPO enzymes activities}

PAL activity was affected by cultivars, storage times and temperatures (Figure 10). PAL activity was significantly higher at 2 than at $5{ }^{\circ} \mathrm{C}$ for all blood orange cultivars. PAL activity sharply increased up to 30 days in the cultivars at $2{ }^{\circ} \mathrm{C}$ and then decreased to the end of storage. 'Moro' and 'Sanguinello' had the lowest and the highest PAL activity, respectively. 


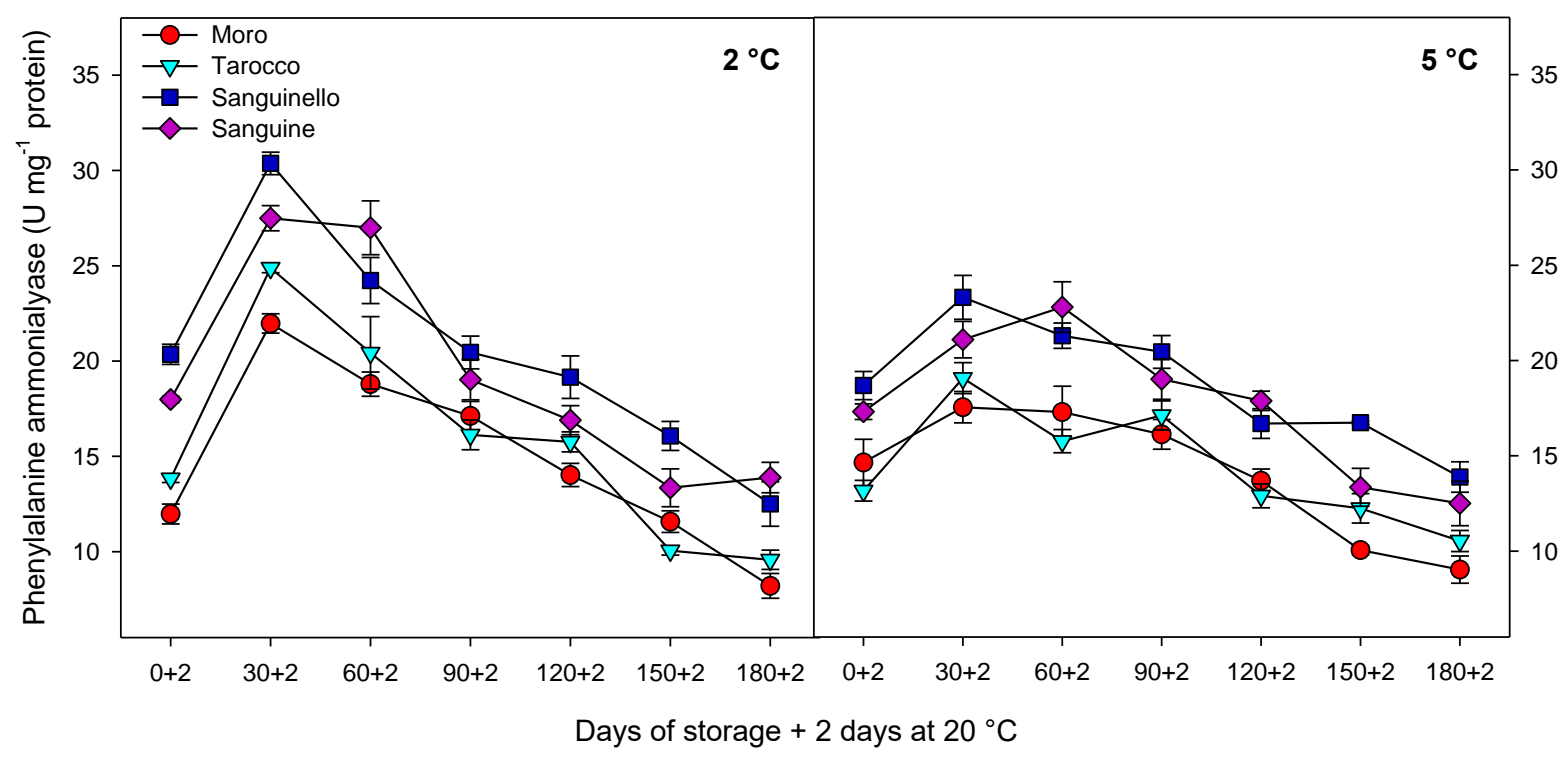

Figure 10. Changes in phenylalanine ammonia-lyase (PAL) enzyme activity in the flavedo of blood orange cultivars ('Moro', 'Tarocco', 'Sanguinello' and 'Sanguine') during cold storage at 2 and $5{ }^{\circ} \mathrm{C}$ and $90 \%$ RH plus 2 days at $20^{\circ} \mathrm{C}$. Vertical bars represent \pm standard error (SE) of means. LSD $(p<$ $0.05)$ value is 2.33 .

PPO activity was significantly affected by cultivars during cold storage. The highest and the lowest PPO activity was found for the 'Moro' and 'Sanguinello', respectively, at both temperatures (Figure 11). There was no significant difference between 'Tarocco' and 'Sanguine' for PPO activity. As shown in Figure 11, the activity of PPO for all cultivars increased up to 60 days, and then decreased along storage. However, at the end of storage, PPO activity slightly increased in 'Tarocco' and 'Sanguinello' at $2{ }^{\circ} \mathrm{C}$ and 'Moro' and 'Sanguine' at $5{ }^{\circ} \mathrm{C}$.

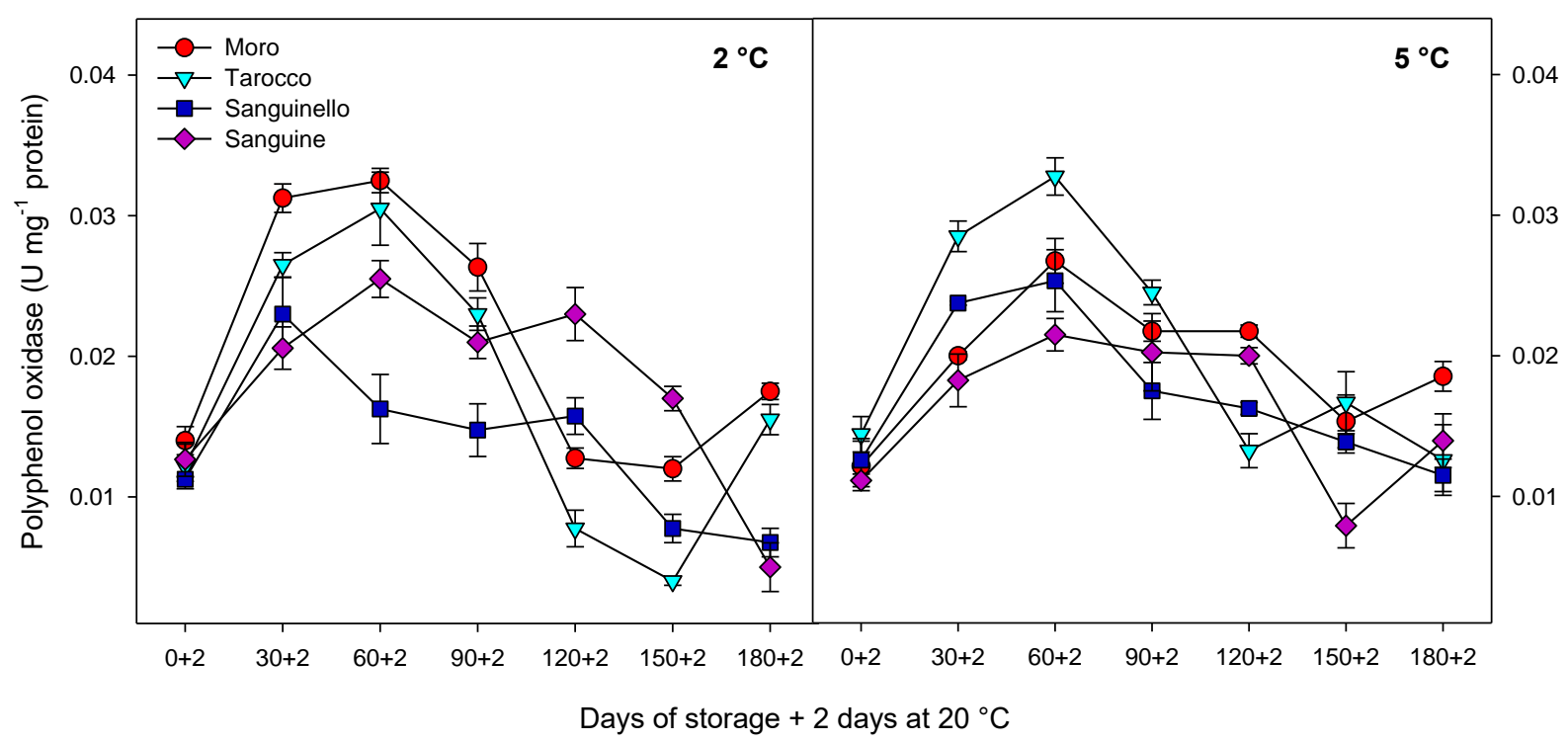

Figure 11. Changes in polyphenol oxidase (PPO) enzyme activity in the flavedo of blood orange cultivars ('Moro', 'Tarocco', 'Sanguinello' and 'Sanguine') during cold storage at 2 and $5{ }^{\circ} \mathrm{C}$ and $90 \%$ $\mathrm{RH}$ plus 2 days at $20^{\circ} \mathrm{C}$. Vertical bars represent \pm standard error (SE) of means. $\operatorname{LSD}(p<0.05)$ value is 0.007 . 


\subsection{Hierarchical clustering analysis (HCA)}

HCA of the cultivars, temperatures and parameters are represented in Figure 12. HCA for cultivars and temperatures revealed four main clusters (Figure 12A). First cluster included 'Moro' and 'Tarocco' at $2{ }^{\circ} \mathrm{C}$, and second cluster included 'Moro' and 'Tarocco' at $5{ }^{\circ} \mathrm{C}$. Third cluster involved 'Sanguinello' and 'Sanguine' at $2{ }^{\circ} \mathrm{C}$, and forth cluster included 'Sanguinello' and 'Sanguine' at $5{ }^{\circ} \mathrm{C}$. In addition, HCA revealed two main clusters for the measured parameters (Figure 12B). $\mathrm{CI}, \mathrm{H}_{2} \mathrm{O}_{2}$ and MDA contents, EL and PPO are included in the first cluster, while proline content, CAT, APX, SOD, POD and PAL were found in the second cluster.
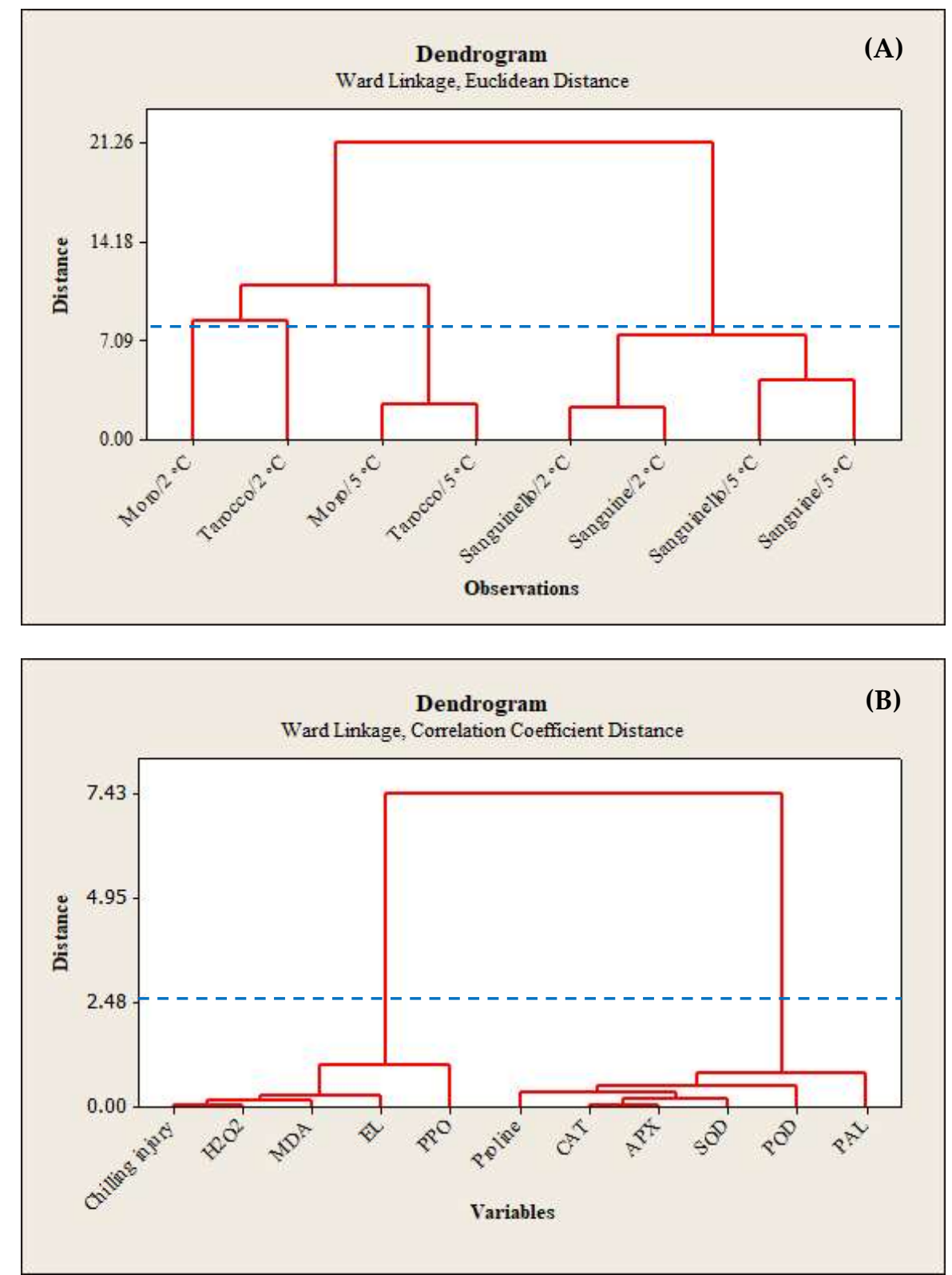

Figure 12. Hierarchical clustering analysis (HCA) of the cultivars and temperatures (A) and parameters (B) of blood orange cultivars ('Moro', 'Tarocco', 'Sanguinello' and 'Sanguine') during cold storage at 2 and $5{ }^{\circ} \mathrm{C}$ and $90 \% \mathrm{RH}$ plus 2 days at $20^{\circ} \mathrm{C}$.

\section{Discussion}

With regard to sensitivity of blood oranges to CI, it is essential to increase the knowledge about the fruit physiological and biochemical responses in order to identify their susceptibility to cold temperature stress. Since cold temperature can prolong postharvest life of blood oranges, therefore the use of low temperature is unavoidable [22]. In this study, susceptibility of blood orange cultivars 
to CI was significantly different at both temperatures, since occurrence of CI symptoms during storage was significantly higher at 2 than at $5{ }^{\circ} \mathrm{C}$. 'Moro' and 'Tarocco' showed severe CI symptoms at $2{ }^{\circ} \mathrm{C}$ plus 2 days at $20^{\circ} \mathrm{C}$ and according to HCA (Figure 12A), 'Moro' and 'Tarocco' were close together at $2{ }^{\circ} \mathrm{C}$ or $5{ }^{\circ} \mathrm{C}$ during storage, while 'Sanguinello' and 'Sanguine' were in same cluster at both temperatures.

Citrus fruit peel is considered the main target of occurrence of postharvest physiological disorders, especially CI symptoms [8, 23]. Based on SEM micrographs, the epidermis structure of the peel of the cultivars represented the CI severity. Cold-sensitive cultivars showed higher fractures, cuticular ridges, rough surface and fissured wax crusts at low temperatures. 'Moro' and 'Tarocco' had severe fractures and cuticular ridges on the peel. On the contrary, 'Sanguinello' and 'Sanguine' showed lower fractures at both temperatures. In addition, epicuticular wax was lost at $2{ }^{\circ} \mathrm{C}$ which demonstrated the higher $\mathrm{CI}$ incidence compared with $5{ }^{\circ} \mathrm{C}$. In this study, there was a distinct difference in rind thickness among blood orange cultivars but rind thickness of blood oranges cultivars was not correlated with $\mathrm{CI}$ tolerance $\left(\mathrm{R}^{2}=0.47\right.$ and 0.37$)$ for 2 and $5{ }^{\circ} \mathrm{C}$, respectively. For example, 'Sanguine' had a thin peel in comparison with 'Moro' and 'Tarocco' but it was a cold-tolerant cultivar. In addition, it has been reported that higher rind thickness in two citrus cultivars may be correlated with reduced postharvest peel pitting [23].

In blood oranges, occurrence of CI symptoms is the result of a series of physiological and biochemical responses to cold temperature. The main symptoms of CI include stem-end rind breakdown, tissue softening, internal and external browning and higher susceptibility to diseases [8, 24]. Primary responses to $C I$ at the cellular level include changes in the fruit membranes and structures, which affect the membrane permeability. Low temperature affects membrane lipid phase transitions and formation of gel phase lipids leads to increased permeability or leakiness of cellular membranes in stored fruit [25]. Secondary, responses include symptoms such as electrolyte release, decrease in metabolic energy, oxidative damage and cellular lysis $[6,26]$. Therefore, EL is a good indicator of membrane permeability and peroxidation of membrane fatty acids [27]. EL significantly increased for all cultivars during storage at both temperatures. In addition, lipid peroxidation is another effect of cold stress. MDA is a secondary end product of peroxidation of membrane unsaturated fatty acid at critical temperature [7]. Furthermore, MDA is recognized as a biomarker for oxidative stress and its product negatively correlated with cell membrane integrity (Habibi et al., 2019). Based on HCA, EL and MDA content were located in the same cluster with CI (Figure 12B). In this study, EL and MDA at $2{ }^{\circ} \mathrm{C}$ were higher than at $5{ }^{\circ} \mathrm{C}$ and also, their amount was significantly different among cultivars. 'Moro' and 'Tarocco' had the highest EL and MDA at $2{ }^{\circ} \mathrm{C}$, showing that lipid peroxidation in these cultivars was more pronounced than 'Sanguinello' and 'Sanguine'.

Oxidative stress is the secondary response of susceptible fruit to CI. Stored fruit at critical temperature generate ROS which subsequently damage of cellular components due to the oxidative stress [28]. On the other hand, ROS accumulation including $\mathrm{H}_{2} \mathrm{O}_{2}$, singlet oxygen, superoxide and hydroxyl radicals are one of the main reasons for incidence of $\mathrm{CI}$ symptoms due to oxidative damage to cell membrane [29]. $\mathrm{H}_{2} \mathrm{O}_{2}$ can enhance membrane lipid peroxidation and oxidative damage at low temperature. In this study, according to $\mathrm{HCA}, \mathrm{CI}$ and $\mathrm{H}_{2} \mathrm{O}_{2}$ content were located in the same cluster (Figure $12 \mathrm{~B}$ ). $\mathrm{H}_{2} \mathrm{O}_{2}$ content was significantly different among cultivars at both temperatures. $\mathrm{H}_{2} \mathrm{O}_{2}$ accumulation at 2 was greater than at $5{ }^{\circ} \mathrm{C}$, but 'Sanguinello' and 'Sanguine' had the lowest $\mathrm{H}_{2} \mathrm{O}_{2}$ content which could be due to a more efficient antioxidant system.

Antioxidant enzymes including CAT, APX, and SOD play an important role in scavenging of ROS and protecting the cell membrane, subsequently decreasing CI in stored fruit at critical temperature [7]. Furthermore, enhanced levels of these enzymes have been correlated to chilling tolerance in fruit stored at critical temperature [27]. The antioxidant defence system includes a series of reactions against oxidative stress and protect components of the cell. For example, SOD is the first line of defence system and catalyses hydrogen peroxide to superoxide anion, removes singlet oxygen, and prevents formation of hydroxide radical. Both CAT and APX decompose the hydrogen peroxide to $\mathrm{H}_{2} \mathrm{O}$ and $\mathrm{O}_{2}$ during cold stress [30]. However, CAT is considered as a key and main enzyme of antioxidant system that is stimulated under oxidative stress caused by CI [29]. In our 
study CAT, APX, SOD and POD activities were higher at $5{ }^{\circ} \mathrm{C}$ than at $2{ }^{\circ} \mathrm{C}$ for all blood orange cultivars. This result may be due to injury to cell membrane components and in turn inducing the transition and formation of the flexible crystal-liquid form to a solid-gel phase at low temperatures [25]. Therefore, the main reason of occurrence of CI symptoms in these cultivars was probably ROS overproduction due to reduction of antioxidant activities. In this study, among the cultivars, 'Sanguinello' and 'Sanguine' had the highest levels of antioxidant enzyme activities at both temperatures. In addition, the lowest activity of antioxidant enzymes was found in 'Moro' and 'Tarocco', which had the highest susceptibility to CI. Therefore, higher antioxidant enzyme activities in blood orange cultivars significantly eliminated $\mathrm{H}_{2} \mathrm{O}_{2}$ content and reduced the incidence of $\mathrm{CI}$. Antioxidant enzymes in all cultivars increased up to 60-90 days during storage and then decreased, which might be due to reduction of energy status or fruit senescence leading to production of $\mathrm{H}_{2} \mathrm{O}_{2}$ which predominated over the antioxidant enzymes scavenging activity.

Proline has a contribution to integrity and stability of cellular membranes, membrane structures, ROS scavenging, protein protection and balances the cytoplasmic osmotic potential, leading to increase fruit resistance to CI [31]. Furthermore, proline accumulation is an adaptive mechanism to help fruit cell against damage of oxidative stress during the low temperature storage [8]. Recently, research showed that proline accumulation can enhance chilling tolerance in stored fruit at critical temperatures. In accordance with this, proline is positively correlated with chilling tolerance in blood orange fruit [8]. In our study, the lowest and highest proline content was observed in 'Moro' and 'Sanguinello', respectively, while there was no significant difference between 'Tarocco', and 'Sanguine', and therefore proline could maintain membrane integrity through osmoregulation at chilling temperature [7].

PAL activity has been considered as a defence mechanism of cold stored fruit in response to chilling stress [8, 28, 31]. Cold temperature can enhance PAL activity in blood orange by up-regulating PAL codifying genes in response to chilling stress [9]. In this sense, PAL mRNA accumulated in mandarin fruit during storage at low temperature $\left(2^{\circ} \mathrm{C}\right)$, which was related to the sensitivity of citrus fruit to $\mathrm{CI}$ [32]. In addition, induction of PAL is required for producing some metabolites that can help the cold stored fruit to resist chilling stress [33]. In this study, PAL activity was significantly different in orange cultivars and storage temperatures. 'Sanguinello' and 'Moro' had the highest and the lowest PAL activity, respectively, during storage. In addition, PAL activity at $2{ }^{\circ} \mathrm{C}$ was higher than at $5{ }^{\circ} \mathrm{C}$ for all blood oranges cultivars. PAL activity is a good biochemical marker for evaluating chilling tolerance in fruit during low temperature storage since enhancement of PAL activity was associated with increased chilling tolerance in blood orange fruit. Furthermore, PAL activity is important to reduce chilling symptoms and postharvest physiological disorders of fruit exposure to cold stress [34]. In the present study, PAL enzyme was correlated with chilling tolerance of blood orange fruit according to HCA. However, PAL activity sharply increased up to 60 days and then decreased to the end of storage. This evidence would permit the inference that the increase in PAL at the initial occurrence of CI symptoms may reveal the initiation of cellular component damage. Therefore, severity of $\mathrm{CI}$ in blood oranges cultivars would be dependent on the intensity of cell damage associated with potential of physiological and biochemical responses at cold stress. This event probably is due to reduction in activity of antioxidant enzymes, fruit senescence as well as reduction of cellular energy that induced CI symptoms in blood oranges cultivars [8].

In this study, HCA showed that CI in blood orange cultivars could be also attributed to PPO activity (Figure 12B). The lowest PPO activity was found in 'Sanguinello' at both temperatures. PPO activity increased up to 60 days in all cultivars, and then decreased to the end of storage. PPO is responsible for oxidation of phenols to highly toxic quinones during cold stress. In addition, PPO activity can oxidize antioxidants, subsequently decreasing the antioxidant activity of cold stored fruit and leading to induce CI and loss of membrane integrity during cold storage [8]. Therefore, low PPO activity appears to be related to a lower CI symptom in 'Sanguinello' cultivar. On the other hand, cold sensitivity of 'Moro' associated with the lower PAL and higher PPO enzyme activities. 


\section{Conclusions}

This is the first comprehensive study for chilling tolerance of blood orange cultivars at low temperatures. Rind thickness of blood oranges cultivars was not correlated with chilling tolerance. According to $\mathrm{HCA}, \mathrm{H}_{2} \mathrm{O}_{2}$, MDA, EL and PPO were located in the same cluster with $\mathrm{CI}$. On the contrary, proline content, antioxidant activity and PAL had correlated for enhancing chilling tolerance. 'Sanguinello' and 'Sanguine' stored at low temperatures were more tolerant to chilling stress, probably due to a more efficient antioxidant enzymes activities and higher PAL and PPO than sensitive cultivars. On the basis of these findings, order of susceptibility of cultivars to CI was 'Moro'> 'Tarocco'> 'Sanguine'> 'Sanguinello'. In future, the change of bioactive compounds with antioxidant activity of these cultivars merits further investigation.

Author Contributions: Conceptualization, F.H. and D.V.; methodology, F.H.; software, F.H. and D.V.; validation, D.V., M.S., F.G., A.R. and D.M.R.; formal analysis, F.H.; investigation, F.H.; resources, D.V.; data curation, D.V., M.S., and F.G., A.R.; writing-original draft preparation, F.H.; writing-review and editing, D.V., M.S., and F.G.; visualization, D.V. and M.S.; supervision, D.V.; project administration, D.V.; funding acquisition, A.R. All authors have read and agreed to the published version of the manuscript.

Funding: This research received no external funding.

Acknowledgments: We would like to thanks to Shiraz University Research Council for financial support and University Miguel Hernández for sabbatical opportunity of Fariborz Habibi. Also, we thank Dashtenaz company, for providing blood oranges cultivars.

Conflicts of Interest: The authors declare no conflict of interest.

\section{References}

1. Habibi, F.; Ramezanian, A. Vacuum infiltration of putrescine enhances bioactive compounds and maintains quality of blood orange during cold storage. Food Chem. 2017, 227, 1-8. https://doi.org/10.1016/j.foodchem.2017.01.057

2. Molinu, M.G.; Dore, A.; Palma, A.; D'Aquino, S.; Azara, E.; Rodov, V.; D'hallewin, G. Effect of superatmospheric oxygen storage on the content of phytonutrients in 'Sanguinello Comune'blood orange. Postharvest Biol. Technol. 2016, 112, 24-30. https://doi.org/10.1016/j.postharvbio.2015.09.037

3. Butelli, E.; Licciardello, C.; Zhang, Y.; Liu, J.; Mackay, S.; Bailey, P.; Reforgiato-Recupero, G.; Martin, C. Retrotransposons control fruit-specific, cold-dependent accumulation of anthocyanins in blood oranges. The Plant Cell 2012, 24, 1242-1255. https://doi.org/10.1105/tpc.111.095232

4. Fallico, B.; Ballistreri, G.; Arena, E.; Brighina, S.; Rapisarda, P. Bioactive compounds in blood oranges (Citrus sinensis (L.) Osbeck): Level and intake. Food Chem. 2017, 215, 67-75. https://doi.org/10.1016/j.foodchem.2016.07.142

5. Hodgson, R.W. Horticultural varieties of Citrus. In: Reuther, W., Webber, H.J., \& Batchelor, L.D. (Eds.), The Citrus Industry. Vol. 1, University of California, 1967, pp. 431-591.

6. Yang, A.; Cao, S.; Yang, Z.; Cai, Y.; Zheng, Y. $\gamma$-Aminobutyric acid treatment reduces chilling injury and activates the defence response of peach fruit. Food Chem. 2011, 129, 1619-1622. https://doi.org/10.1016/j.foodchem.2011.06.018

7. Wang, Y.; Luo, Z.; Huang, X.; Yang, K.; Gao, S.; Du, R. Effect of exogenous $\gamma$-aminobutyric acid (GABA) treatment on chilling injury and antioxidant capacity in banana peel. Sci. Hortic. 2014, 168, 132-137. https://doi.org/10.1016/j.scienta.2014.01.022

8. Habibi, F.; Ramezanian, A.; Rahemi, M.; Eshghi, S.; Guillén, F.; Serrano, M.; Valero, D. Postharvest treatments with $\gamma$-aminobutyric acid, methyl jasmonate, or methyl salicylate enhance chilling tolerance of blood orange fruit at prolonged cold storage. J. Sci. Food Agric. 2019, 99, 6408-6417. https://doi.org/10.1002/jsfa.9920

9. Lo Piero, A.R.; Puglisi, I.; Rapisarda, P.; Petrone, G. Anthocyanins accumulation and related gene expression in red orange fruit induced by low temperature storage. J. Agric. Food Chem. 2005, 53, 9083-9088. https://doi.org/10.1021/jf051609s 
10. Rehman, M.; Singh, Z.; Khurshid, T. Alleviation of chilling injury induced by cold quarantine treatment in Midknight Valencia and Lane Late sweet orange fruit. Aust. J. Crop Sci. 2018, 12, 1616. https://doi.org/10.21475/ajcs.18.12.10.p1197

11. Rapisarda, P.; Bellomo, S.E.; Intelisano, S. Storage temperature effects on blood orange fruit quality. J. Agric. Food Chem. 2001, 49, 3230-3235. https://doi.org/10.1021/jf0100321

12. Palma, A.; D’Aquino, S.; Vanadia, S.; Angioni, A.; Schirra, M. Cold quarantine responses of 'Tarocco' oranges to short hot water and thiabendazole postharvest dip treatments. Postharvest Biol. and Technol. 2013, 78, 24-33. https://doi.org/10.1016/j.postharvbio.2012.12.002

13. Nukuntornprakit, O.-a.; Chanjirakul, K.; van Doorn, W.G.; Siriphanich, J. Chilling injury in pineapple fruit: Fatty acid composition and antioxidant metabolism. Postharvest Biol. and Technol. 2015, 99, 20-26. https://doi.org/10.1016/j.postharvbio.2014.07.010

14. Shang, H.; Cao, S.; Yang, Z.; Cai, Y.; Zheng, Y. Effect of exogenous $\gamma$-aminobutyric acid treatment on proline accumulation and chilling injury in peach fruit after long-term cold storage. J. Agric. Food Chem. 2011, 59, 1264-1268. https://doi.org/10.1021/jf104424z

15. Bradford, M.M. A rapid and sensitive method for the quantitation of microgram quantities of protein utilizing the principle of protein-dye binding. Anal. Biochem. 1976, 72, 248-254. https://doi.org/10.1016/0003-2697(76)90527-3

16. Chance, B.; Maehly, A. Assay of catalases and peroxidases.. Methods in Enzymol. 1955, 2, 764-775. https://doi.org/10.1016/S0076-6879(55)02300-8

17. Nakano, Y.; Asada, K. Hydrogen peroxide is scavenged by ascorbate-specific peroxidase in spinach chloroplasts. Plant and cell physiol. 1981, 22, 867-880. https://doi.org/10.1093/oxfordjournals.pcp.a076232

18. Beauchamp, C.; Fridovich, I. Superoxide dismutase: improved assays and an assay applicable to acrylamide gels. Anal. Biochem. 1971, 44, 276-287. https://doi.org/10.1016/0003-2697(71)90370-8

19. Liu, Q.; Xi, Z.; Gao, J.; Meng, Y.; Lin, S.; Zhang, Z. Effects of exogenous 24-epibrassinolide to control grey mould and maintain postharvest quality of table grapes. Int. J. Food Sci. Tech. 2016, 51, 1236-1243. https://doi.org/10.1111/ijfs.13066

20. Silva, C.R.d.; Koblitz, M.G.B. Partial characterization and inactivation of peroxidases and polyphenol-oxidases of umbu-cajá (Spondias spp.). Food Sci. Technol. 2010, 30, 790-796. https://doi.org/10.1590/S0101-20612010000300035

21. Khorram, F.; Ramezanian, A.; Hosseini, S.M.H. Shellac, gelatin and Persian gum as alternative coating for orange fruit. Sci. Hortic. 2017, 225, 22-28. https://doi.org/10.1016/j.scienta.2017.06.045

22. Habibi, F.; Ramezanian, A.; Guillén, F.; Serrano, M.; Valero, D. Blood oranges maintain bioactive compounds and nutritional quality by postharvest treatments with $\gamma$-aminobutyric acid, methyl jasmonate or methyl salicylate during cold storage. Food Chem. 2020, 306, 125634. https://doi.org/10.1016/j.foodchem.2019.125634

23. Cronjé, P.J.; Zacarías, L.; Alférez, F. Susceptibility to postharvest peel pitting in Citrus fruits as related to albedo thickness, water loss and phospholipase activity. Postharvest Biol. Technol. 2017, 123, 77-82. https://doi.org/10.1016/j.postharvbio.2016.08.012

24. Lafuente, M.T.; Zacarias, L. Postharvest physiological disorders in citrus fruit. Stewart Postharvest Rev. 2006, 2(1), 1-9. https://doi.org/10.2212/spr.2006.1.2

25. Cao, S.; Yang, Z.; Cai, Y.; Zheng, Y. Fatty acid composition and antioxidant system in relation to susceptibility of loquat fruit to chilling injury. Food Chem. 2011, 127, 1777-1783. https://doi.org/10.1016/j.foodchem.2011.02.059

26. Valero, D.; Serrano, M. Postharvest biology and technology for preserving fruit quality; CRC press: 2010. Taylor \& Francis-CRC Press, Boca Raton, Florida, USA.

27. Jin, P.; Zhu, H.; Wang, J.; Chen, J.; Wang, X.; Zheng, Y. Effect of methyl jasmonate on energy metabolism in peach fruit during chilling stress. J. Sci. Food Agric. 2013, 93, 1827-1832. https://doi.org/10.1002/jsfa.5973

28. Siboza, X.I.; Bertling, I.; Odindo, A.O. Enzymatic antioxidants in response to methyl jasmonate and salicylic acid and their effect on chilling tolerance in lemon fruit [Citrus limon (L.) Burm. F.]. Sci. Hortic. 2017, 225, 659-667.https://doi.org/10.1016/j.scienta.2017.07.023

29. Sevillano, L.; Sanchez-Ballesta, M.T.; Romojaro, F.; Flores, F.B. Physiological, hormonal and molecular mechanisms regulating chilling injury in horticultural species. Postharvest technologies applied to reduce its impact. J. Sci. Food Agric. 2009, 89, 555-573. https://doi.org/10.1002/jsfa.3468 
30. Huang, R.-H.; Liu, J.-H.; Lu, Y.-M.; Xia, R.-X. Effect of salicylic acid on the antioxidant system in the pulp of 'Cara Cara' navel orange (Citrus sinensis L. Osbeck) at different storage temperatures. Postharvest Biol. Technol. 2008, 47, 168-175. https://doi.org/10.1016/j.postharvbio.2007.06.018

31. Sun, H.; Luo, M.; Zhou, X.; Zhou, Q.; Sun, Y.; Ge, W.; Wei, B.; Cheng, S.; Ji, S. Exogenous glycine betaine treatment alleviates low temperature-induced pericarp browning of 'Nanguo'pears by regulating antioxidant enzymes and proline metabolism. Food Chem. 2020, 306, 125626. https://doi.org/10.1016/j.foodchem.2019.125626

32. Sanchez-Ballesta, M.; Zacarias, L.; Granell, A.; Lafuente, M. Accumulation of PAL transcript and PAL activity as affected by heat-conditioning and low-temperature storage and its relation to chilling sensitivity in mandarin fruits. J. agric. Food Chem. 2000, 48, 2726-2731. https://doi.org/10.1021/jf991141r

33. Sayyari, M.; Babalar, M.; Kalantari, S.; Serrano, M.; Valero, D. Effect of salicylic acid treatment on reducing chilling injury in stored pomegranates. Postharvest Biol. Technol. 2009, 53, 152-154. https://doi.org/10.1016/j.postharvbio.2009.03.005

34. Lafuente, M.a.T.; Zacarias, L.; Martínez-Téllez, M.A.; Sanchez-Ballesta, M.a.T.; Granell, A. Phenylalanine ammonia-lyase and ethylene in relation to chilling injury as affected by fruit age in citrus. Postharvest Biol. Technol. 2003, 29, 309-318. https://doi.org/10.1016/S0925-5214(03)00047-4 